chileno, sino más bien con el argentino. Acaso el autor piensa de igual manera y por eso ha lanzado su libro a la circulación en Buenos Aires.

En cambio, a través de todas sus páginas se advierte una minuciosa y exacta relación de las exterioridades de los bajos fondos. El anochecer en el barrio de las prostitutas; los hotelillos para pasajeros; las casas de cita; toda la mise-enscène está bien presentada. Observaciones justas, ambiente propio, diseñado con cariño, con el apego que a tales barrios tiene un buen noctámbulo andariego.

En la parte susceptible de ser vivida, esto es en aquello que está al alcance de una persona que no pertenece a esos bajos fondos, que sólo contempla más o menos de cerca su existencia, el autor actúa con maestría. Don Fide, el borracho impenitente, bueno en el fondo, incapaz de una canallada como las de Angelito, muere un buen día. El vecindario vindica su memoria. Don Fide se transforma en mito religioso. Se le encienden velas, se le piden gracias, milagros. La viuda, que había pasado siempre inadvertida a los ojos del barrio, adquiere respetabilidad, situación. Las virtudes del finado se recuerdan, se agigantan; los vicios se olvidan. Su viuda llora inconsolablemente. Procura hacer un velorio.

Un buen ataúd, un velorio sonado y la sepulturita son en el cielo, como el traje nuevo, el pañuelo de seda y los zapatos flamantes, una credencial de decencia.

El mejor trozo del libro, el más verdadero, el más chileno, se encuentra en esta relación. Páginas que muestran un patio del conventillo, con su vida social, sus convencionalismos $\mathrm{y}$ sus exigencias. Constituyen un verdadero acierto.

El resto adolece del defecto antes señalado: están destinadas al público argentino. $-F$. Ortúzar Vial.

BARULA, por Carlos Vattier Bañados.

En realidad no se puede considerar novela este libro (1), de escasas páginas y de parvo tamaño, sino porque el autor ha tenido cuidado de poner la comprometedora palabra bajo el título. Mentalmente el lector recuerda que son novelas libros como Los hermanos Karamazof, de Dostoyevsky, y no puede menos de preguntarse qué ha perseguido el señor Vattier con la publicación de estas páginas. ¿Saciar una sed de publicidad, muy legítima cuando se comienza a escribir? ¿Hacer una confesión de sus propios sentimientos de adolescente y de joven? ¿Esbozar la pintura de un medio social ruinoso y decadente? Creo que es legítimo considerar esta obrita desde los dos últimos puntos de vista.

En lo que toca al primero, Barula es muy confuso, debido en gran parte a la insuficiencia que el autor revela en el manejo del estilo y de la lengua. Hay en este libro muchas frases que seguramente han

(1) Santiago, Imprenta Vera, 
sido escritas para causar en el lector la sorpresa de los rasgos de ingenio. Desgraciadamente, se quedan a medio camino y no logran su objeto. No hay en Barula estilo propio ni... ajeno. Simplemente, no hay estilo. No puede haberlo porque no hay ritmo $y$ porque la frase, que unas veces tiene una ondulación, un tono dado, cambia de golpe, en transiciones bruscas $y$ nada felices. No puede haberlo porque ni la gramática, ni el léxico responden a los propósitos del autor $y$, rebeldes a su designio, se empeñan en jugarle malas pasadas.

La pintura de un determinado medio social es muy insuficiente $y$ si a veces tiene momentos relativamente felices, las más se nos muestra incompleta, carente del reposo indispensable a toda obra de arte que aspire a durar. Atraviesan las páginas de Barula algunos seres extraños, que podrían dar materia a un estudio de patología necesariamente extraliterario. Se trata de cocainómanos, de invertidos, de ratés, que viven en una atmósfera de sueño especialísima. Del conjunto se eleva un olor nauseabundo a vicios de todo género, a inversión sexual, a inadaptación a la vida. Desde luego, quede bien claro que la pintura de ese medio no nos parece mal porque en ella abunden esos seres. Sino porque es incompleta, no define suficientemente ninguna psicología individual y no logra ofrecer al lector ningún perfil humano cabal.

k, Es humano errar, sobre todo en una primera obra, producida al calor de los pocos años y bajo el influjo de recientes lecturas no bien digeridas aún. Pero ¿por qué infligir al público tal género de balbuceos? He aquí un libro del cual pudiera decirse, en conclusión: el autor habría ganado mucho si no lo hubiese publicado. Seguramente esta misma será su opinión cuando hayan pasado los años y de la aventura de hoy no quede más que un leve recuerdo. El recuerdo de un paso falso, que se pagaría mucho dinero por no haber dado.-Raúl Silva Castro.

\section{Viviana y Merlín, por Benjamín Jarnés.}

En un comentario hecho en esta misma revista a la anterior producción de Jarnés, Fernando Ortúzar Vial señalaba como condición primigenia de la obra del literato español la perfección del estilo y Raúl Silva Castro en el estudio sobre Jarnés fijaba la calidad de su estilo único. En esta reciente Viviana y Merlin las opiniones citadas tienen su confirmación más amplia. La leyenda del medioevo se transfigura bajo la pluma de Jarnés y se nos aparece como una producción en la que la más pura modernidad en la frase $y$ en la manera de componer tiene un exponente valioso.

Viviana la hechicera y Merlín el mago se arrancan, en un viaje de amor a través de todas las edades, de las vetustas antesalas de la corte del Rey Arturo. Con ellos caminan la gracia y la sabiduría y 